mer Windings After Shutdown by V. M. Montsinger, which was scheduled for the Schenectady meeting which was subsequently canceled, will be presented and discussed at this session.

\section{AMENDMENT TO BY-LAWS}

At the meeting of the Board of Directors held April 13, the following by-law, which had been recommended by the Meetings and Papers Committee, was adopted:

Each technical committee shall, at the annual convention, present a report covering the work of the year and giving plans and suggestions for future activities. These reports shall be, whenever practicable, published with discussion.

It is the intention of the chairmen of the various technical committees, all of whom are ex-officio members of the Meetings and Papers Committee, to inaugurate the practise of presenting an annual report, at the Annual Convention of the Institute to be held at Hot Springs, Va., June 26-29, 1917.

\section{THE ENGINEERING SOCIETIES IN NATIONAL DEFENSE}

By Gano Dunn, Chairman

Engineering Committee, National Research Council.

The engineering profession which has been so prompt to volunteer its professional and military services to the Government in support of National Defense is now in contact with the various Government agencies, as follows:

First, through the Naval Consulting Board and its formerly existing Committee on Industrial Preparedness, with the origin and organization of which Board the engineering profession is already familiar. Each of the National Engineering Societies and certain other Societies by contributing two members to the Naval Consulting Board has afforded the Navy and War Departments and the Council of National Defense a highly expert Board for passing upon inventions and developing them in the new Government Laboratory that has been organized.

Second, in a more or less informal way, through the joint Committee on Engineer's Reserve Corps and the Military Engineering Committee of New York, the military services of engineers are being organized and offered to the Government, and an Engineer's Regiment is recruiting in New York.

The Constitutions of some of the National Engineering Societies were found to contain such limitations that these Societies could not take formal action in military matters. A little over a year ago the Military Engineering Committee organized itself through the spontaneous action of a group of leading engineers, including a number of Presidents, Past Presidents and other prominent officers of the National Engineering Societies to an extent that gave the Committee a character representative of those Societies although this character has only recently been confirmed by the action of the Societies themselves.

Third, through the National Research Council created at the request of President Wilson by the National Academy of Sciences, "to bring into cooperation existing Governmental, educational, industrial and other scientific and research organizations with the purpose of encouraging investigations of natural phenomena, the increased use of scientific research in the develupment of American industries, the employment of scientific methods in strengthening the National Defense, and such other applications of science as will promote the National security and welfare."

The work of the National Research Council, the offices of which adjoin the offices of the Council of National Defense, is carried on through the agency of central committees covering each of the physical sciences and chemistry, mathematics, medicine, hygiene, agriculture and other subjects, including a Committee on Engineering.

To this Committee on Engineering 
each of the National Engineering Societies has contributed two representatives and stands ready to contribute others as called for. With the engineers who are members of the National Research Council, these constitute the Engineering Committee.

The representatives so far named from the American Society of Civil Engineers are George F. Swain, Edgar C. Marburg and Clemens Herschel; from the American Institute of Mining Engineers, Pope Yeatman, Albert Sauveur, Charles F. Rand and George K. Burgess; from the American Society of Mechanical Engineers, W. F. M. Goss, John R. Freeman, C. D. Young, Wm. F. Durand, John A. Brashear, Hollis Godfrey, Howard E. Coffin and Ambrose Swasey; from the American Institute of Electrical Engineers, Frank B. Jewett, Clayton H. Sharp, Gano Dunn, C. E. Skinner, Michael I. Pupin, S. W. Stratton, Elihu Thomson and John J. Carty; from the American Institute of Consulting Engineers, Lewis B. Stillwell.

This Engineering Committee under formal request of the Council of $\mathrm{Na}$ tional Defense in a resolution dated February 28th, 1917, addressed to the National Research Council brings to the aid of the National Defense Council directly through its Director, the professional services of engineers in the realm of engineering research, and it constitutes the connection between the Council of National Defense and the various National Engineering Societies through which services offered by those Societies to the President of the United States may be called upon in the solution of problems in scientific and engineering research.

In addition to supporting the Government in Engineering Research this Committee also brings to the aid of the Government through the National Research Council such general engineering services as are auxiliary to research where these services are needed by any of the other Committees of the Council as incidental to research problems on which they are at work.
The National Engineering Societies have a further relation to the National Research Council through the Engineering Foundation which these Societies established to administer the munificent gift of Ambrose Swasey for the fostering of research in science and engineering. Through the action of the engineers the whole available income from this gift is now devoted to the organization and operation expenses but not the research expenses of the Council.

As has been stated, the contact of the engineering profession with National Defense through the Engineering Committee of the National Research Council covers only those services involved in science and engineering research with the addition of such general engineering services as are auxiliary.

Other, or general services in the engineering field are articulated with the National Defense as follows:

Fourth, through an Engineering Section of that Committee of the Advisory Commission of the Council of National Defense which is under the direction of Dr. Hollis Godfrey, to whom the Defense Council has assigned supervision of general engineering matters, including education.

Dr. Godfrey is now in course of completing the formation of this Committee by calling upon each National Engineering Society and certain other Engineering Societies to contribute two representatives whom he may appoint members of the Engineering Section of his Committee, so that services needed by the Council of National Defense in the realm of general engineering may be placed at its disposal, either by the individual members of the Committee or through them by other members of the Engineering Societies upon whom the Council of National Defense may call.

The above four channels indicate the broad extent to which the members of the engineering profession, in patriotic response to the Country's need, have come forward to render services. 